\title{
FARMING IN MARLBOROUGH
}

J. P. BEGGS, Farm Advisory Officer, Department of Agriculture, Blenheim.

There is little chance in dealing with a wide subject such as this in the short period of 20 minutes of doing justice to the various facets of farming in Marlborough Province and I can only hope to outline briefly the more important types of farming and perhaps to stress the more striking features of primary production in the area.

\section{EARLY DEVELOPMENT}

Since early times sheep have been to the forefront in Marlborough farming. The New Zealand Company planned to start development in Marlborough in 1843, but the Wairau incident delayed operations for a time. In $1847 \mathrm{Mr} \mathrm{G}$. Clifford (later Sir George) and Sir Frederick Weld brought 3,000 sheep from Sydney and established the Flaxbourne run; and $\mathrm{Mr} \mathrm{N}$. G. Morse and $\mathrm{Dr}$ Cooper drove a flock of sheep from Waimea to Tophouse. Then followed Messrs G. Duppa (Birch Hill), C. F. Watt (Landsdowne), and A. J. Jenkins (Hillersden).

By 1850 occupation licences were issued for 45 runs, well known ones being Hawkesbury, Starborough, Upton Downs, Blairich, The Delta, Benhopai, Leefield, Upcot, Gladstone, and the famous Molesworth.

Agricultural farming, too, commenced in 1847 , when there was a general influx to the lower Wairau Plain. Swamps had to be drained, bush felled, and much trouble was experienced as a result of frequent flooding of the Wairau River.

After 1860 there was a temporary farming setback due to labour going to public works and to the discovery of gold in 1864 . In that year there were 456,000 sheep in the Province and 8,189 acres in crop.

Lowland runs were then subdivided, 22 large runs becoming 543 holdings. However, lack of transport held up development of the Province considerably. The railway from Picton reached the Opawa River in 1885 and Seddon in 1902, and after many delays Picton became linked to Christchurch only in 1945.

Recently, of course, air transport and now the improved railferry service have broken down the isolation of New Zealand's most central province. 


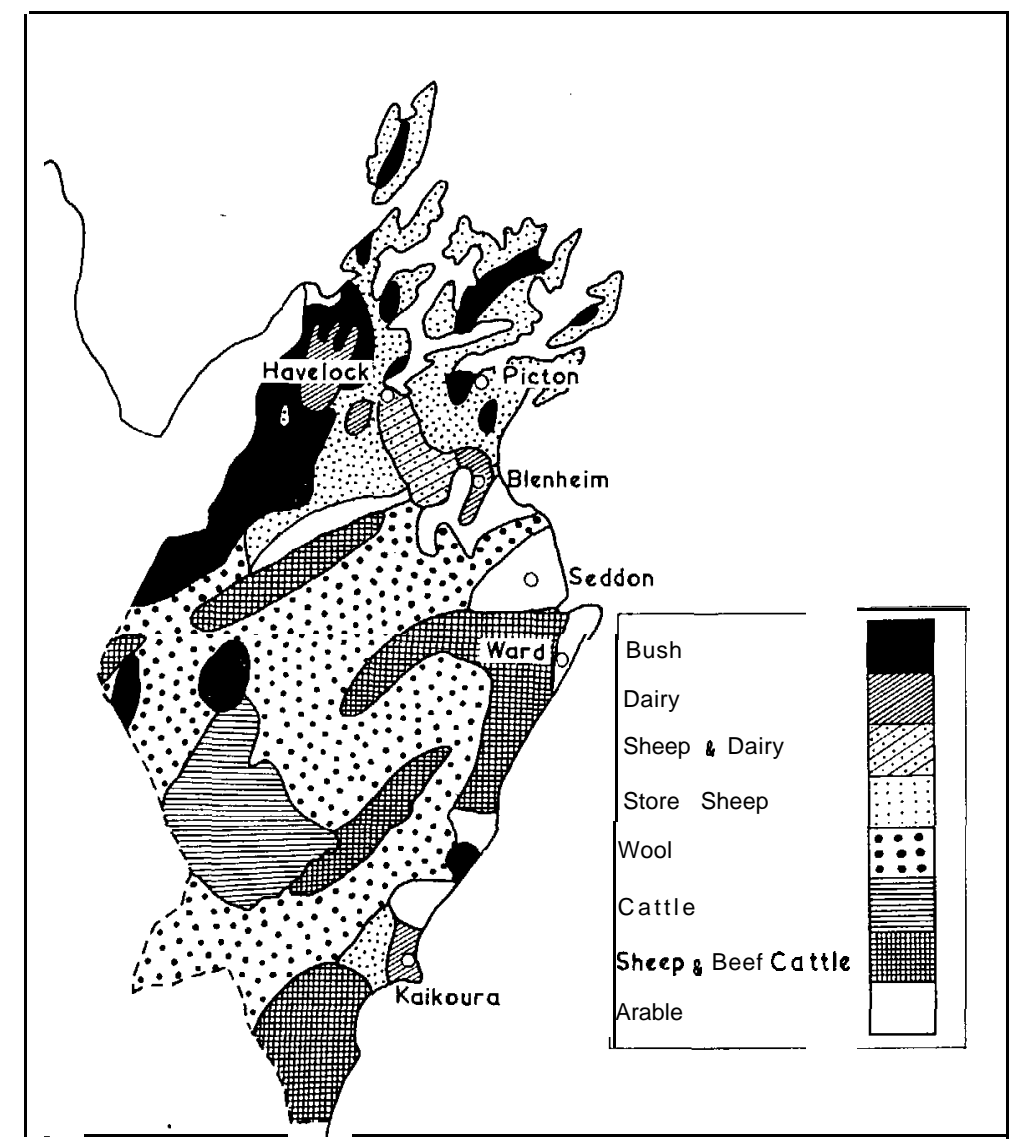

Fig. 1 (Map) : Farming patterns in Marlborough.

\section{TOPOGRAPHY}

Farming in an area is always controlled by topography and this is certainly a most important feature in Marlborough. In general, the Province can be said to be hilly to mountainous, with relatively small areas of flat land separated by hills or mountain ranges. Most of Marlborough is either steep or flat country. Undulating portions are not extensive, the main area of this type being round Seddon and Ward.

Perhaps, for convenience, the district could he divided into three main topographical units :

1. Northern Hill Country: This is steep, often rugged country lying to the north of the Wairau River. It contains narrow valleys with very small but very useful areas of flat land. 
Altitude ranges from sea level to over $4,000 \mathrm{ft}$ inland. In the Sounds area most of the valley floors have been invaded by the sea and little flat land remains.

2. Lower Wairau and Awatere Valleys: This area is composed of flat to undulating country, where most of the arable farming is carried out.

3. Southern Hills and Kaikoura Ranges: A big proportion of this is steep, rugged country ranging to over 9,000 ft. Mt. Tapuaenuku $(9,465 \mathrm{ft})$, the highest point in New Zealand outside the Southern Alps, dominates this high country.

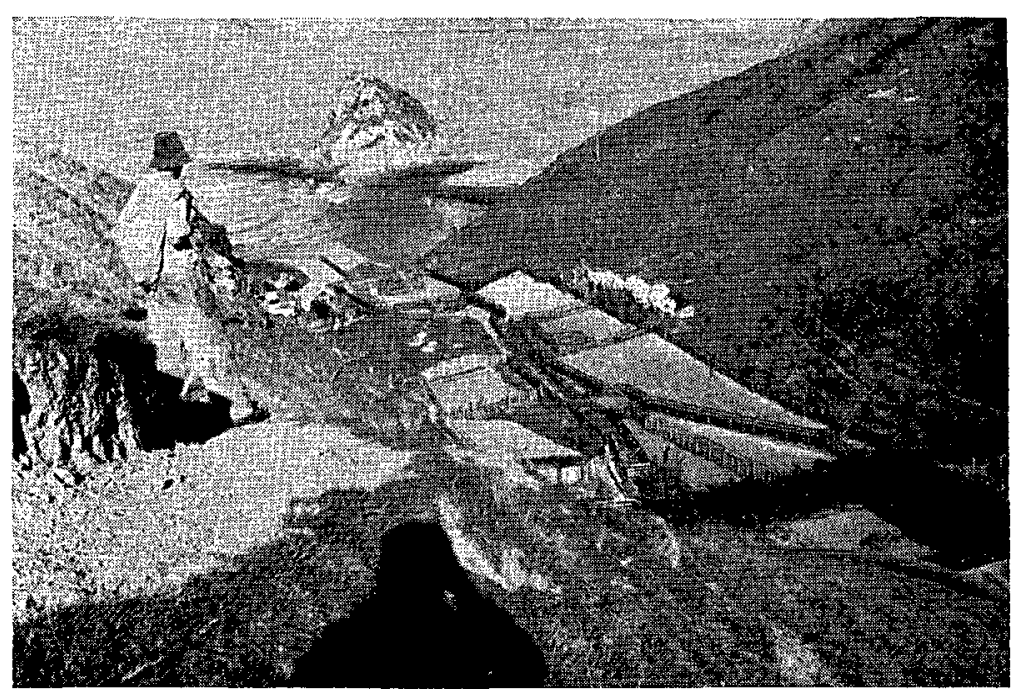

Fig. 2: Flat land for the placement of buildings and sheep yards is very limited in the Marlborough Sounds.

There are other areas of flat land not included in this general classification, the most significant being the Wairau Valley lightland flats and the small area of heavy flat land adjacent to Kaikoura township.

It is of interest to note that whereas about 36 per cent of Canterbury is cultivated, only about 14 per cent of Marlborough falls into this class.

\section{CLIMATE}

As would be expected from the topography, the climate varies greatly from place to place. Rainfall, for example, rises rapidly from 25 in. at Blenheim to 45 in. just 7 miles north and 64 in. at Picton. (Fig. 3.) Havelock has a similar rainfall to Picton while at Rai Valley the level rises to 86 in. The Seddon rainfall is about 
the same as Blenheim's though somewhat less effective owing to more windy conditions. At Kaikoura the average precipitation is 36 in. and at Wairau Valley 39 in., while Molesworth is the driest locality with $24 \mathrm{in}$. The rainfall is spread fairly evenly through the year with a tendency to be somewhat lower in summer.

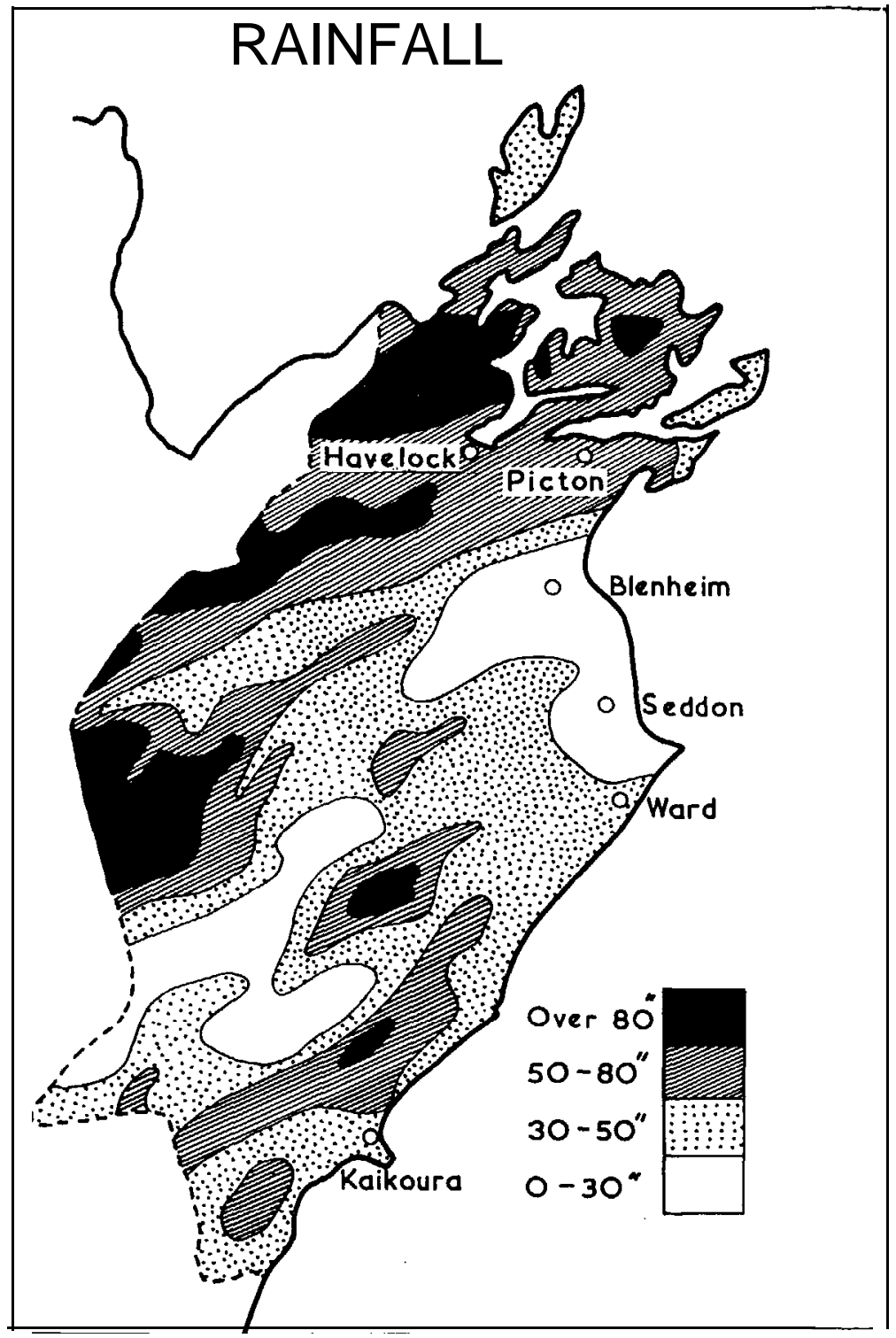

Fig. 3: Rainfall map of Marlborough. 
At Blenheim frosts are said to be common and actually total 104 annually (occurring in about $\mathbf{3} \frac{1}{2}$ months). However, Molesworth experiences 224 frosts annually or about $7 \frac{1}{2}$ months of them.

Blenheim had the largest annual duration of sunshine in New Zealand for nine consecutive years before 1957 and achieved this again in 1961. This sunny climate makes the district very favourable for the production of high quality seeds.

\section{SOILS}

Mr H. S. Gibbs has already given a detailed description of Marlborough soils and I shall only reiterate that the area of flat, fertile soils in Marlborough is small and, in general, we must depend on fertility-building operations for any great increase in production.

\section{TYPES OF FARMING}

I shall now deal briefly with the main types of farming carried on in different parts of the Province.

\section{Sheep Farming}

Sheep farming in the Province commenced in 1847, when two main lots of sheep were brought in. Since then sheep farming has remained the most important type of farming and I think the topography of the area will dictate that it shall continue to be.

Over the years good quality sheep have been bred to suit the conditions and the health of the sheep generally is good.

In the high country and lower rainfall hill country to the south of the Wairau River the main breeds are the Halfbred, Corriedale, and Merino with some Romneys on the lower hills. In recent years Romneys have increased proportionately more than other breeds in the Province and there is a tendency for Merinos to be replaced to some extent by Halfbreds.

On the higher country, wool only is produced. The lower hills provide the sheep breeding country; here, mainly Corriedales, Halfbreds, and Romneys are run and at stock sales sound and failing mouth ewes, wethers, store lambs of both sexes, and calves are sold, Old cows go to the works and occasionally some steers may be fattened. Some fattening of sheep is done on a few properties which have some easier country.

Ten years ago the Halfbred was the predominant sheep breed in the Province, but its place has now been taken by the Romney. This changeover reflects the improvement that has taken place on the hill country. Corriedales are next in number to Halfhreds, with Merinos following. 
Beef cattle numbers have increased appreciably in recent years, and this development has assisted greatly in the control of rank pasture and weeds. Further increases in cattle numbers are both likely and desirable, although farmers in areas subject to periodic droughts have to be careful not to proceed too far in this respect.

\section{M ixed Farming}

There are various types of mixed farming. The main one is mixed arable cropping and fat lamb production plus small seeds production. There are also sheep plus dairying, sheep plus small seeds production, and dairying plus small seeds production.

The main centre of intensive mixed cropping and fat lamb production is the lower Wairau Plain area surrounding Blenheim,



Fig. 4: Onions are only one of the many crops grown for seed production in the vicinity of Blenheim. High incidence of sunshine favours good quality in seeds.

Tuamarina, Spring Creek, Fairhall and Rapaura. This area includes the best cropping land in the Province and the high amount of sunshine promotes good quality in all types of seeds and also provides ideal harvesting conditions. Yields of barley and wheat on the best of this land at times exceed 100 bushels per acre.

The main cash crops are wheat, peas, and barley. Over the last five years, since the opening of a quick-freeze factory, an appreciable area of peas and beans (both broad and runner) have also been grown for processing. Sweet corn is used in smaller quantities.

The following table for the 1959-60 season shows the main cash and fodder crops and their importance in relation to the national economy: 


\section{Area Under Crops, 1959-60}

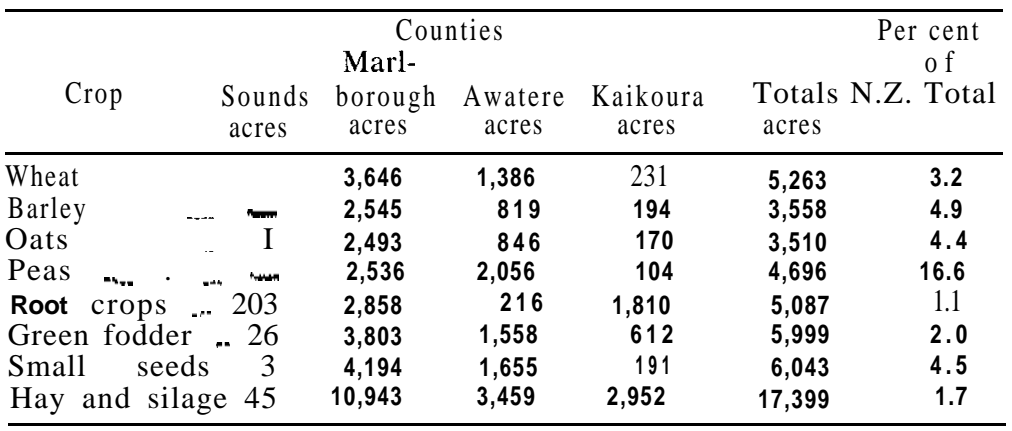

The wheat acreage has shown more alteration than that of any other crop in recent years, and in the current season it is estimated that the area sown has risen to over 6,000 acres.

Marlborough's pea acreage forms an appreciable proportion of the Dominion total (up to 20 per cent in some years) and it is probable that the growing of this crop is more concentrated in the vicinity of Blenheim than in any other part of the country.

Of the small seeds, cowgrass is the main crop with lucernc, perennial ryegrass, and white clover also prominent. Most other types of small seeds are also produced in the district in smaller quantities. Blenheim is the principal centre for the growing of onion seed crops as well as most other garden and flower seeds. These seed crops are grown on a part-paddock basis on cropping farms in the area. Flower seeds are frequently grown on urban household sections.

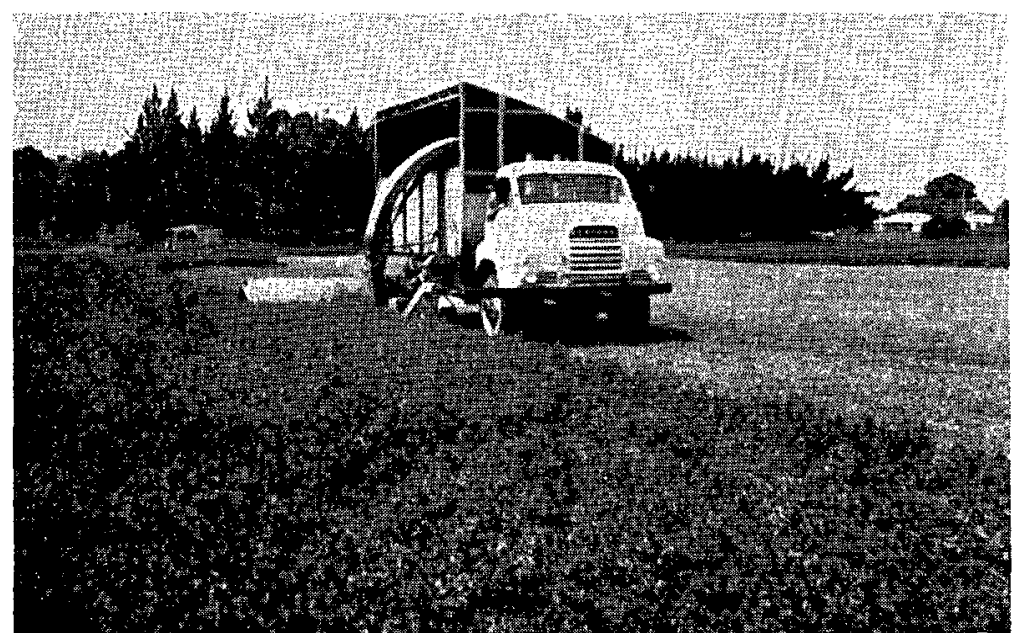

Fig. 5: Harvesting lucerne for immediate processing into meal and pellets. 
Hay and silage are produced largely from lucerne and cowgrass stands but also from pasture. A further outlet for farm production in the vicinity of Blenheim is provided by the lucerne meal factory.

Normally, on the intensive mixed farming country ewes are bought in each year for fat lamb production and wethers and store lambs may also be purchased and fattened. The Romney is the predominant breed, but Corriedale and Halfbred ewes are also commonly used.

Another important centre of mixed arable farming and fat lamb production is Seddon, although properties are larger here and the emphasis is more on sheep than cropping. The main crops are peas and wheat; but barley, oats, lucerne, ryegrass and white clover are also important. Lucerne seed production is quite concentrated and successful in the Grassmere district south of Seddon. Mr G. A. Avery will tell you about this on Thursday.

Other centres of mixed farming are Ward and Hillersden, although there is still less emphasis on cropping in these areas. In the Kaituna, Canvastown, Rai Valley areas cowgrass seed production is commonly associated with both dairying and fat lamb production. Its common, too, in these narrow valleys in the highrainfall districts for sheep to be run on the hill country and dairy cows on the flats, for most properties are composed of flats at the front and hill country at the back.

\section{Dairying}

Dairying is not widespread in Marlborough, but is important in a few localities such as Rai Valley, Mahakipawa, Koromiko, and Kaikoura. There are cheese factories at Rai Valley, Koromiko, and Tuamarina and butter factories at Blenheim and Kaikoura. Town milk supply as well as some ordinary dairy farms are located on the lower Wairau Plain.

\section{Orchards and Market Gardens}

There are upward of 500 acres of bearing orchards in the Province. Apples form about 80 per cent of the total crop, the remainder being mainly pears and peaches. Cherries are also produced. About 90 per cent of the orchard area is concentrated on the stony soils of the Rapaura area. Apple production has increased by about 60 per cent in the last 10 years,

The market garden area for the production of fresh vegetables is static to declining, but the area in crops for processing has increased greatly in the last few years.

Glasshouse tomatoes arc an important crop and Blenheim is the earliest producer of this crop in the South Island. 


\section{IRRIGATION}

Though no community irrigation scheme exists in Marlborough, many individual farmers have systems of pumping from streams or wells. Spray irrigation is used almost exclusively and is most common on dairy and mixed farms on the lower Wairau Plain. On mixed farms irrigation water is used mostly on pea, lucerne, and potato crops.

\section{FARMING IN THE SOUNDS}

Farmers in the Marlborough Sounds face many difficult and unusual conditions, the most notable being transport problems and costs. All transport is by water: sheep and cattle are punted, groceries go out by launch, the future house cow in the form of a calf goes out on the mail launch, a trip to town (which does not come often) is made, at least part of the way, by launch, and the mail arrives by launch (twice a week).

All this makes for high transport costs and much handling. For example, landing of lime on the beach and putting it under cover is not an easy operation; it is still harder to go out and sow it by hand on the hills.

The country is almost all hills and most properties have only enough flat land for the placement of buildings. The country is of very low fertility, and, as it is difficult and costly to apply fertiliser, the battle against weeds (fern, tauhinu, and Spanish heath) is continuous and difficult. It is necessary to use fire frequently to keep this second growth at bay.

The sheep carried are mostly Romneys, and store stock are produced, ewes being sold for fat lamb production in more favoured parts of the Province. A few farmers who have an area of flats are able to fatten some of the lambs. However, the aeroplane is now operating on many properties in the Sounds and this will assist greatly in the control of weeds and will permit more fattening of stock to be done.

\section{SOIL EROSION AND RABBITS}

Marlborough has had something of an unwanted reputation for soil erosion, but I think this has been due largely to the existence of large areas of denuded country when the rabbit was rampant. Actually, with minor exceptions such as the Wither Hills area, the soils of the Province are not susceptible to serious erosion. With removal of the rabbit (as a result of excellent work by Rabbit Boards) and control of other injurious wildlife, signs of any widespread erosion, apart from the incurable type on the mountain tops, are largely disappearing. 


\section{LAND DEVELOPMENT}

Quite appreciable progress is being made in land development in Marlborough. Areas of previously unimproved flat land are now being cultivated and the crawler tractor is advancing to the limit of safety up the hillsides.

Where the tractor gives up, the aeroplane takes over, and it is in this field that most progress is being made, for it is here that most of our unimproved land lies. Even on the poorest hill country the proper application of seed and fertiliser is working wonders, but this work is expensive and finance is a problem.

\section{The Weed Problem}

Owing to the large area of fairly low fertility hill country in the area weeds are a serious problem. Gorse, Spanish heath, bracken fern, tauhinu, and broom, are the more common and troublesome weeds on hill country, particularly in the low fertility, high-rainfall areas. Nassella tussock, of course, is a very serious one on the drier hill country although control of this weed has progressed very satisfactorily in Marlborough.

With the control of the rabbit, sweet brier has become a difficult problem in some parts. However, I shall now leave this serious problem "in the air", for I am sure that Messrs Leonard, Inch, and Madden will deal fully and capably with this important subject.

\section{THE FUTURE}

The future of Marlborough lies in its hills; and I am not referring to the presence of gold or uranium, but a more practical and reliable commodity-grass. Although scope still remains for further development of some of our very limited area of flat land, this is not great compared with the vast area of hill country that remains untouched. Aerial topdressing coupled with research work is greatly simplifying the problem of improving our hill country and it is important that this work should go ahead with all possible speed in Marlborough, before serious weeds such as gorse and Spanish heath have taken over and made the job much more expensive or perhaps uneconomic.

There are, too, other avenues of production apart from pasture and no doubt many farmers will avail themselves of the new scheme for increased forestry work, for much of this poor, weedinfested country I have referred to is ideal for the growing of trees.

I am confident, therefore, that, while we have many problems to surmount in Marlborough farming, the future is anything but gloomy; I am sure the bounteous sunshine we enjoy will continue 
to give us a rich harvest of seed from the plains, the winds of Grassmere will not fail to bring in an inexhaustible harvest from the sea, and the hill farmer with the research worker and the aeroplane to assist him will ensure that our vast expanse of hill country will yield an ever-increasing harvest of the "golden" fleece.

\section{DISCUSSION}

Q. How far have we got with the destruction of the rabbit?

A. As I am not an authority on rabbits I am diffident about answering this. Twenty or thirty years ago the district was alive with rabbits but you don't often see a rabbit now when driving round the district. Even on Molesworth the rabbits have been greatly reduced and the vegetation has recovered. However, the rabbit remains a continuing problem from the point of view of holding the present position.

Comment (1. L. Elliott): In the early thirties when I worked in this district the hills were so thick with rabbits that they gave the impression of being fields of waving grass.

Q. Now that you are rid of rabbits do you have a sweet brier problem as they do in Central Otago. If so, do you have an eradication scheme?

A. I do not know Central Otago well enough to make a comparison. However, since the rabbit has gone this weed is a problem.

Q. (Mr O'Reilly): What is the pattern of topdressing of the hill country in Marlborough? Is it normal to introduce clovers first?

A. In most of the hill country south of Blenheim we find a sulphur response and we topdress with sulphurised super at the rate of $1-2 \mathrm{cwt}$ per acre. To the north we use molybdic super at $3 \mathrm{cwt}$ per acre for a start to give an initial boost.

The normal pattern is to sow clovers first as it is difficult to get a strike of grass first. In the northern areas where you have difficulty with fern or other weed growth you get a good strike of both grass and clover after a burn.

Q. Are you concerned about the introduction of weeds when sowing grass from the air? A recent sowing of mine showed the presence of considerable nodding thistle.

A. I am concerned about all weeds. Under the certification scheme only a percentage of weed seeds is permitted but it is impossible to get pure seed and we have to accept that there is a possibility of some weed seeds in any mixture we buy.

Comment (Mrs M. Johnstone): A line of seed consists of say 100 bags from which a $4 \mathrm{oz}$ sample is drawn and examined at the Seed Testing Station. From this sample 1,500 seeds are drawn for testing and the remainder is searched for weed seeds. Accuracy therefore depends on the sample drawn. There is a potential danger of weeds and I feel that the crop should be subject to rigid inspection before it is harvested.

Comment (Chairman): The department is very concerned about this problem and is taking every precaution but in spite of this it is practically impossible to eliminate all weeds.

Comment: Mr S. H. Saxby outlined the purpose of the certification scheme and said that a senior official had arranged to visit the district to discuss this problem. 